\title{
Natural history of Gynaikothrips uzeli (Thysanoptera, Phlaeothripidae) in galls of Ficus benjamina (Rosales, Moraceae)
}

\author{
André Luiz S. Mascarenhas \& Juvenal C. Silva Junior ${ }^{2}$
}

\begin{abstract}
1. Programa de Pós-graduação em Genética, Conservação e Biologia Evolutiva, Grupo de Pesquisa em Abelhas, Instituto Nacional de Pesquisa da Amazônia, INPA/GPA, Av. André Araújo, 2936, 69067-375 Petrópolis, Manaus, AM, Brasil. (andre masc@yahoo.com.br)

2. Departamento de Ciências Biológicas, Programa de Pós-Graduação em Genética, Biodiversidade e Conservação, Universidade Estadual do Sudoeste da Bahia, UESB, Rua José Moreira Sobrinho, s/n, 45206-190 Jequié, BA, Brasil. (juvenaljr@yahoo.com.br )
\end{abstract}

Received 21 March 2015

Accepted 15 July 2016

DOI: $10.1590 / 1678-4766 e 2015016$

\begin{abstract}
Galls induced by thrips are simple structures when compared to those of other groups of arthropods, and little is known regarding many of their aspects. This study aimed to investigate aspects of the natural history of Gynaikothrips uzeli Zimmermann, 1900 in galls of Ficus benjamina L., 1753 using seasonal sampling (summer and winter). Twenty trees were sampled and divided into quadrants. From each of them, five galls were collected, forming a total of 400 galls per collection. Thrips showed greater abundance at higher temperatures $\left(25.7^{\circ} \mathrm{C}\right)$ and no precipitation. Sex ratio was biased towards females ( 0.022 males per female), pointing to an inbred mating structure. Arthropod fauna associated with galls was more abundant $(\mathrm{N}=798)$ in winter, and it included representatives of the orders Hemiptera, Hymenoptera, Araneae, Coleoptera, Neuroptera, Psocoptera, Thysanoptera, Diptera and Blattodea.
\end{abstract}

KEYWORDS. Leaf galls, natural enemies, sex ratio, thrips.

RESUMO. História natural de Gynaikothrips uzeli (Thysanoptera, Phlaeothripidae) em galhas de Ficus benjamina (Rosales, Moraceae). As galhas induzidas por tripes são estruturas simples quando comparadas com outros grupos de artrópodes e pouco conhecidas quanto a diversos aspectos. Este trabalho teve como objetivo verificar aspectos da história natural de Gynaikothrips uzeli Zimmermann, 1900 em galhas de Ficus benjamina L., 1753 em coletas sazonais (verão e inverno). Vinte árvores escolhidas, aleatoriamente, foram divididas em quatro quadrantes, e em cada um deles coletadas cinco galhas, perfazendo um total de 400 galhas por coleta. Os tripes apresentaram uma maior abundância em temperaturas mais elevadas $\left(25,7^{\circ} \mathrm{C}\right)$ e sem precipitação. A razão sexual (0,022 machos) encontrada foi baixa (tendenciosa às fêmeas), apontando para uma estrutura endogâmica de acasalamento. A fauna associada de artrópodes presentes nas galhas foi mais abundante $(\mathrm{N}=798)$ no período de inverno e incluiu representantes das ordens Hemiptera, Hymenoptera, Araneae, Coleoptera, Neuroptera, Psocoptera, Thysanoptera, Diptera e Blattodea.

PALAVRAS-CHAVE. Galha foliar, inimigos naturais, razão sexual, tripes.

The Thysanoptera, or thrips, exhibit a remarkable dietary diversity, encompassing predatory, mycophagous and phytophagous species (TerRY, 1997; Mound, 2005; RotenBERG \& WhitFIELD, 2010). Their phytophagous diet can cause damage to several parts of plants, and many species are gall inducers - among these, the genus Gynaikothrips Zimmermann, 1900. Association between gall-forming thrips and host plants is a specialized trophic strategy and, in some cases, it is also species-specific (ANANTHAKRISHNAN, 1993).

Ficus benjamina L., 1753 is widely used in urban tree planting (SANTos \& RAmalho, 1997) and it has been used in studies due to its antibacterial potential (RESCHKE et al., 2007). The galls induced by Gynaikothrips uzeli Zimmermann, 1900 in F. benjamina are characterized by the folding of the leaf due to the insects feeding on the leaf tissue (Retana-SalazAR \& Sánchez-Chacón, 2009), bringing this species into a pest status. Besides providing a food source, the galls also serve as shelter and protection from predators, as well as shelter to inquiline species belonging to different arthropod orders (Mound et al., 1995; GoNÇALVES-ALVIM \& FERNANDES, 2001).

Despite its cosmopolitan distribution and economic importance, a few studies on the biology of Gynaikothrips uzeli have been conducted. Among them, we highlight FARONG et al. (1995), who studied biological characteristics (rate of emergence, average amount of spawned egg, rate of hatchability, and span of life) of G. uzeli in Jinggu, China; Held et al. (2005), who conducted a study on the distribution and a revision of the biology of G. uzeli in the southwestern United States; and DE Melo et al. (2013), who accessed the behavior and predatory potential of Androthrips ramanchandrai Karny, 1926 to G. uzeli.

Therefore, this research aims to characterize the galls induced by Gynaikothrips uzeli in Ficus benjamina through seasonal sampling (summer and winter) regarding the abundance of adult and immature inducer individuals, the sexual rate and the relation with the leaf area and with the gall stage. Furthermore, we looked for the effects of average 
temperature and precipitation on G. uzeli abundance, and we determined the fauna associated with the galls.

\section{MATERIALS AND METHODS}

Galls were collected from trees of Ficus benjamina (Moraceae) in Jequié, state of Bahia (1352'4.9"S, $\left.40^{\circ} 04^{\prime} 26.7^{\prime \prime} \mathrm{W}\right)$, during the period of February 1 st to 10 th (summer), and from July 25th to August 3rd, 2012 (winter). In order to collect galls, 20 trees with different canopy sizes were selected, and each one was divided into four quadrants. Then, five galls were sampled from each quadrant, totalizing 400 galls per collection period (800 in total).

The galls were placed individually into plastic bags and transported to the Laboratory of Insect Biology (LABI) at Universidade Estadual do Sudoeste da Bahia (UESB), where they were analyzed. Each gall was washed internally with $70 \%$ ethanol, and the obtained material was put into a Petri dish. The material was then inspected under a stereomicroscope to search for adults, immature (larval, pre-pupal and pupal stages) and associated arthropods, which were all counted. Individuals were fixed in absolute ethanol, placed in plastic vials of $2 \mathrm{~mL}$, and identified to the most specific taxonomic level with support of experts. For identifying the sex of Gynaikothrips uzeli, we took into account the sexual dimorphism of the species, in which adult males are smaller than females (GARITA-CAMBRONERO \& LIZANO-FALLAS, 2006). In cases which sex identification was ambiguous, specimens were dissected in order to inspect the genitalia.

In order to establish the relation between gall stages and abundance of individuals, galls were collected and classified into three stages considering leaf texture and folding capacity: young gall leaves, which were flexible and partially folded; mature gall leaves, which were minimally flexible and folded; and old galls, which had inflexible, overdried and twined leaves. Leaf area was calculated using the formula proposed by AmAzONAS et al. (2008): $\mathrm{A}_{\mathrm{E}}=\pi \cdot \mathrm{ab}=(3.14$. $\mathrm{CW}) / 4=0.785 . \mathrm{CW}(\mathrm{C}$, length and $\mathrm{W}$, width).

The sex ratio of adult thrips was determined as the ratio between the total number of males and number of females (Quicke, 1997). The analysis of variance (ANOVA) was performed to verify a significant difference between the averages of leaf area, abundance of Gynaikothrips uzeli, general associated fauna, Montandoniola moraguesi Puton, 1896, and Androthrips ramachandrai Karny, 1926 in different gall stages of summer and winter periods. Pearson correlations were also calculated in order to test the correlation between leaf area with following variables: total of $G$. uzeli, A. ramachandrai, $M$. moraguesi and other associated arthropods and the program SAS/STAT version 8.0 (SAS Institut, 2003) was used.

\section{RESULTS AND DISCUSSION}

Results obtained from the analysis of 800 galls induced by Gynaikothrips uzeli in Ficus benjamina are summarized in Tab. I.

The data revealed a greater abundance of Gynaikothrips uzeli in summer compared to winter. This decrease is partially due to the influence of the temperature. The summer average temperature was about $25.7^{\circ} \mathrm{C}$, while in winter the average temperature was about $22.0^{\circ} \mathrm{C}$. There was no rainfall during the period of collections. Under those conditions of high temperature and decreased precipitation the biological cycles are usually accelerated, promoting the population growth. In the analysis performed by PAINE (1992), e.g. developmental time (from egg to adult) in Gynaikothrips ficorum Marchal, 1908 varied from 48.99 days at $15^{\circ} \mathrm{C}$ to 16 days at $30^{\circ} \mathrm{C}$ (thermal limits were $12^{\circ} \mathrm{C}$ and $35^{\circ} \mathrm{C}$ ). Thus, the abundance of $G$. uzeli in summer may be a consequence of a shorter life cycle and a higher chance of overlapping generations. Moreover, heavy rains could carry individuals away from galls when the latter are not completely formed, or inundate them, when they are already formed.

Another important factor is that, during the winter, the associated fauna was more abundant and diverse. Furthermore, Gynaikothrips uzeli predators were present in greater quantity, mainly Montandoniola moraguesi (Tab. II), resulting in a sharp decrease in the number of immature individuals (Tab. I).

According to ANANTHAKRISHNAN (1993), besides the galling species, galls harbor other secondary species that may be inquilines, parasites, predators, or occasional visitors. Among predators, there are hemipterans, other thrips, ants, flies, wasps, neuropteran larvae, mites, spiders and pseudoscorpions (MonTEIRO \& MOUND, 2012).

In the current work, we found specimens of nine orders of arthropods (Tab. II), which shows that the ecological interactions involving galls induced by Gynaikothrips uzeli are quite diverse.

Among specimens of the gall associated fauna, we highlight Montandoniola moraguesi and Androthrips ramachandrai due to their abundance and previously known predatory relationship with G. uzeli (DoBBs \& BoyD JR., 2006; De Melo et al., 2013).

Tab. I. Data from the analysis of 800 galls of Ficus benjamina L., 1753 induced by Gynaikothrips uzeli Zimmermann, 1900 with 400 galls collected in summer and 400 collected in winter.

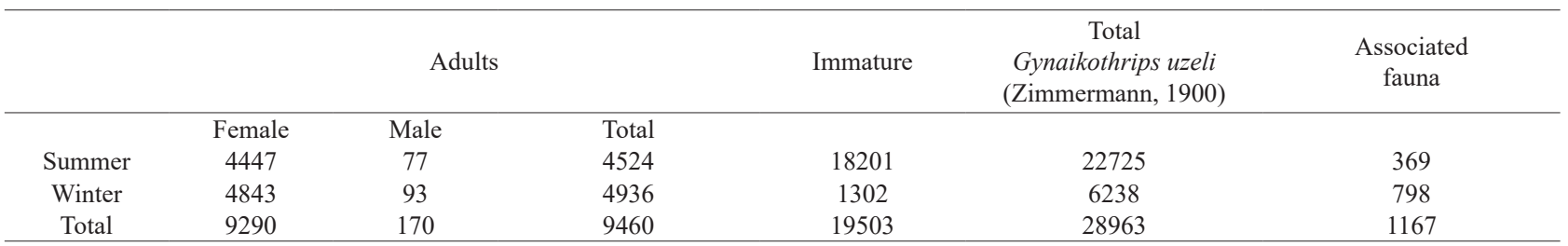


Tab. II. Taxonomic classification of the fauna associated with galls of Ficus benjamina L., 1753 induced by Gynaikothrips uzeli Zimmermann, 1900 during collections in summer and winter times, indicating the numbers of immature (IM) and adult individuals (AD).

\begin{tabular}{|c|c|c|c|c|c|c|}
\hline \multirow[t]{2}{*}{ Orders } & & \multirow[t]{2}{*}{ Taxon } & \multicolumn{2}{|c|}{ Summer } & \multicolumn{2}{|c|}{ Winter } \\
\hline & & & IM & $\mathrm{AD}$ & IM & $\mathrm{AD}$ \\
\hline \multirow[t]{3}{*}{ Araneae } & Thomisidae & & - & - & - & 2 \\
\hline & Sicaridae & & - & - & - & 1 \\
\hline & - & & 5 & - & 23 & - \\
\hline Blattodea & - & & - & - & 1 & - \\
\hline Coleoptera & - & & - & 1 & - & 7 \\
\hline Diptera & - & & - & - & - & 1 \\
\hline \multirow[t]{2}{*}{ Hemiptera } & Aleyrodidae & & 14 & - & 11 & - \\
\hline & Anthocoridae & Montandoniola moraguesi (Puton,1896) & 124 & 47 & 405 & 91 \\
\hline \multirow[t]{5}{*}{ Hymenoptera } & Formicidae & Nylanderia sp. & - & 1 & - & - \\
\hline & & Crematogaster sp. & - & 5 & - & - \\
\hline & & Cardiocondyla sp. & - & 1 & - & - \\
\hline & & - & - & 5 & - & 39 \\
\hline & Eulophidae & Tetrastichinae & - & - & 5 & 1 \\
\hline \multirow[t]{2}{*}{ Neuroptera } & Chrysopidae & - & 1 & 1 & - & \\
\hline & Hemerobiidae & - & - & - & 1 & \\
\hline \multirow[t]{4}{*}{ Psocoptera } & - & - & - & 7 & - & \\
\hline & Ectopsocidae & Ectopsocus sp. 1 & - & - & - & 1 \\
\hline & & Ectopsocus sp. 2 & - & - & - & 1 \\
\hline & Pseudocaeciliidae & Pseudocaecilius citricola (Ashmead, 1879) & - & - & - & 1 \\
\hline \multirow[t]{2}{*}{ Thysanoptera } & Thripidae & Selenothrips rubrocinctus (Giard, 1901) & - & - & - & 2 \\
\hline & Phaleothripidae & Androthrips ramachandrai (Karny, 1926) & 21 & 144 & 19 & 178 \\
\hline TOTAL & & & 164 & 205 & 472 & 326 \\
\hline
\end{tabular}

Montandoniola moraguesi was the most abundant insect in the analyzed galls (Tab. II). It is recognized as an effective predator of various species of thrips and it has been used in Hawaii as a biological control agent of Gynaikothrips uzeli since 1966 (DobBS \& BoYd JR., 2006). Although it is considered native from Southeast Asia, this species has already reached cosmopolitan status, being reported in some countries in Africa, Asia, Europe, the Americas and in Australia (FunaSAKI, 1966; Dobbs \& Boyd JR., 2006; PluotSigwalt et al., 2009; SePúlveda Cano et al., 2009). In a study with Gynaikothrips ficorum performed by FUNASAKI (1966), it was reported that the nymphs in the $1^{\text {st }}$ and $2^{\text {nd }}$ instars of $M$. moraguesi feed on eggs and larvae of $G$. ficorum, and nymphs in the $3^{\text {rd }}, 4^{\text {th }}$ and $5^{\text {th }}$ instars feed on thrips at any stage of development, including adults. DobBs \& BoyD JR. (2006) also reported M. moraguesi as a predator of Androthrips ramachandrai.

Another predator of thysanopterans which was abundant in the galls was Androthrips ramachandrai (Tab. II). This species was firstly described in India, and it was already reported in Trinidad and Tobago, Belize, Puerto Rico, United States (Boyd JR. \& Held, 2006), Mexico (CAmberoCAmpos et al., 2010), Colombia (Sepúlveda Cano et al., 2009), Argentina (Borbón \& Agostini, 2011) and Brazil (CAVALLERI et al., 2011) as a predator of various galling thrips, among them Gynaikothrips uzeli (BoYD JR. \& HeLD, 2006). Immature and adult stages of $A$. ramachandrai were observed in laboratory feeding on immature stages of $G$. uzeli and G. ficorum (CAVALLERI et al., 2011). This observation was confirmed by SEPÚLVEDA CANO et al. (2009), who observed that whenever $A$. ramachandrai populations increased, G. uzeli populations decreased. This is also supported by data obtained in the current study (Tabs I, II), given that a decrease in G. uzeli numbers was observed in winter, when A. ramachandrai numbers increased.

The other sampled orders may eventually establish a predatory relationship with $G$. uzeli, and an inquiline or visitation to the formed galls in $F$. benjamina. KAUFMANN et al. (1991) and NADEL et al. (1991), e.g. reported that Formicidae and Coleoptera are related to seed dispersion in several species of Ficus.

We would also like to highlight that this is the first report of specimens of the orders Araneae (Sicariidae), Neuroptera (Hemerobiidae) and Psocoptera associated with galls of Ficus benjamina.

Tab. III presents the average abundance of G. uzeli, general associated fauna, Montandoniola moraguesi and Androthrips ramachandrai in different stages of galls collected in summer and winter. Although mature galls had the highest average - which agrees with the hypothesis proposed by ANANTHAKRISHNAN \& RAMAN (1989) that mature galls would have larger populations, while galls in formation would have smaller populations - the ANOVA was generally non-significant ( $p>0.05$ ), thus indicating no difference between gall averages. However, the relationships between gall stage and leaf area $(\mathrm{F}=11.86 ; \mathrm{df}=2.399 ; p$ $<0.001)$, and total of G. uzeli $(\mathrm{F}=17.51 ; \mathrm{df}=2.399 ; p<$ $0.001)$ in the summer, and the relationships between gall stage and leaf area $(\mathrm{F}=15.83 ; \mathrm{df}=2.399 ; p<0.001)$ and females $(\mathrm{F}=4.37 ; \mathrm{df}=2.399 ; p=0.013)$ in the winter were all statistically significant and indicated that mature galls were different from the others. The correlations considering leaf area were low (Tab. IV). These data indicate both larger and smaller leaves can harbor populations of various sizes.

Sex ratio observed in G. uzeli (Tab. V) suggested a bias toward females. According to CRESPI (1993), the way 
Tab. III. Number of galls, average and standard deviation of leaf area and average of the abundance of Gynaikothrips uzeli Zimmermann, 1900, general associated fauna, Montandoniola moraguesi Puton, 1896 and Androthrips ramachandrai Karny, 1926 in different stages of galls collected in summer and winter.

\begin{tabular}{|c|c|c|c|c|c|c|}
\hline & \multicolumn{3}{|c|}{ Summer } & \multicolumn{3}{|c|}{ Winter } \\
\hline & Young & Mature & Old & Young & Mature & Old \\
\hline Number of galls & 78 & 296 & 26 & 103 & 258 & 39 \\
\hline Leaf Area & $\begin{array}{c}7.64 \pm \\
3.81\end{array}$ & $\begin{array}{c}9.39 \pm \\
3.46\end{array}$ & $\begin{array}{c}6.95 \pm \\
2.47\end{array}$ & $5.44 \pm$ & $7.46 \pm$ & $4.31 \pm$ \\
\hline Gynaikothrips uzeli Zimmermann, 1900 & 18.59 & $\begin{array}{l}3.40 \\
69.1\end{array}$ & 31.58 & $\begin{array}{l}3 . / 1 \\
9.58\end{array}$ & 18.79 & $\begin{array}{l}1.93 \\
10.31\end{array}$ \\
\hline Associated fauna (general) & 0.55 & 1.6 & 0.69 & 1.28 & 2.36 & 1.36 \\
\hline Montandoniola moraguesi Puton, 1896 & 0.12 & 0.53 & 0.19 & 0.44 & 1.57 & 1.1 \\
\hline Androthrips ramachandrai Karny, 1926 & 0.21 & 0.48 & 0.23 & 0.8 & 0.43 & 0.08 \\
\hline
\end{tabular}

Tab. IV. Pearson correlations between Leaf Area (LA) and total of Gynaikothrips uzeli Zimmermann, 1900 (TOT), Androthrips ramachandrai Karny, 1926 (AR), Montandoniola moraguesi Puton, 1896 (MM) and other associated arthropods (OT), collected in summer, winter and both periods (summer + winter) $(*$, significant at $5 \% ; * *$ significant at $1 \%$; ns, non significant).

\begin{tabular}{ccccc}
\hline & TOT & AR & MM & OT \\
\hline LA & $\mathbf{0 , 3 2 1 * *}$ & $-0,057^{\text {ns }}$ & $\mathbf{0 , 1 5 1 * *}$ & $\mathbf{0 , 1 4 5 * *}^{\text {Summer }}$ \\
LA & $\mathbf{0 , 1 4 7 * *}$ & $0,053^{\text {ns }}$ & $\mathbf{0 , 1 9 0 * *}$ & $0,069^{\text {ns }}$ \\
LA & $\mathbf{0 , 3 0 6 * *}$ & $0,016^{\text {ns }}$ & $\mathbf{0 , 1 1 5 * *}$ & $0,048^{\text {ns }}$ \\
\hline
\end{tabular}

Tab. V. Sample size (N) and sex ratio (males per female) of Gynaikothrips uzeli Zimmermann, 1900 collected in summer, winter and total (both periods), by gall stage and general data.

\begin{tabular}{|c|c|c|c|c|c|}
\hline & \multirow{2}{*}{$\mathrm{N}$} & \multicolumn{3}{|c|}{ Gall stage } & \multirow{2}{*}{ General } \\
\hline & & Young & Mature & Old & \\
\hline Summer & 4524 & 0.016 & 0.052 & 0.006 & $0.023 \pm 0.0944$ \\
\hline Winter & 4936 & 0.02 & 0.022 & 0.029 & $0.022 \pm 0.1016$ \\
\hline Total & 9460 & 0.018 & 0.037 & 0.018 & $0.022 \pm 0.098$ \\
\hline
\end{tabular}

in which galls are founded has fundamental importance in understanding sex allocation in thrips, which is reflected in the sex ratio.

Based on studies of Tree \& WALter (2009), who observed that galls of Gynaikothrips ficorum in Ficus microcarpa L.f 1782 are induced by one or occasionally two females, and field observations in the current study, we believe that the formation of galls of G. uzeli is also likely to be carried out by one or a few females. Those founding females possibly mate with a male sibling inside the gall from which they migrated. Such data is ratified by the low heterozygosity observed in a population genetics analysis of G. uzeli in galls of Ficus benjamina (MASCARENHAS et al., 2015).

Tree \& Walter (2009) also observed that Gynaikothrips australis Bagnall, 1929 leaves and returns to its galls throughout the day. This temporary dispersion could also occur in G. uzeli. Such flow could be reflected in the sex ratio, as the adults are the ones involved, but their gender is not clearly defined. Another factor that may explain the low amount of males in galls is that male larvae could be present in the galls but were not detected, since immature individuals were not sexed. Furthermore, the possible presence of Wolbachia Hertig, 1936 bacteria may justify the low amount of males found, given that it has already been reported to affect the reproductive process of some species in Thysanoptera (Kumm \& MoriTz, 2008).

Data from this study indicate a greater abundance of G. uzeli at higher temperatures, and the low number of males may be an indication that one or a few fertilized females are responsible for the foundation process of galls and that inbreeding is a common reproductive process in G. uzeli.
Moreover, sex ratio may be further influenced by adult male dispersion throughout the day and by females infected by Wolbachia bacteria. The arthropod fauna found within galls of Ficus benjamina was diverse, demonstrating that this was a favorable microhabitat for numerous ecological interactions. This study also provided the first records of specimens in the orders Psocoptera, Neuroptera (Hemerobiidae), and Araneae (Sicariidae) associated with galls induced by $G$. uzeli. Additional studies on the pattern of gall foundation, as well as studies on the relatedness among individuals from the same gall may help to elucidate aspects related to reproductive strategies and female dispersal in this species.

Acknowledgments. We are grateful to Ivan Cardoso Nascimento, who identified Formicidae; Fábio Pereira Alves and Lucio Flavio Freire Lima for the identification of Eulophidae; Rogéria Lara for identifying the Neuroptera; Aline Oliveira for identifying araneids, and Alberto Moreira da Silva Neto for identifying psocoterans; Adriano Cavalleri for his contributions in writing the manuscript; and the Fundação de Amparo à Pesquisa do Estado da Bahia (FAPESB) for granting a scholarship to the first author.

\section{REFERENCES}

Amazonas, I. B.; Soares, W. A.; Almeida, C. A. B. \& Uchikawa, R. 2008. Modelagem da estimativa da área foliar da mangueira (Mangifera indica L.). In: $\mathbf{8}^{\mathbf{0}}$ Encontro Regional de Matemática Aplicada e Computacional. Natal, Universidade Federal do Rio Grande do Norte (Natal).

Ananthakrishnan, T. N. 1993. Bionomics of Thrips. Annual Review of Entomology 38:71-92.

Ananthakrishnan, T. N. \& Raman, A. 1989. Thrips and Gall Dynamics. New Delhi, Brill Archive. 108p.

Borbón, C. M. \& Agostini, J. P. 2011. Gynaikothrips uzeli (Zimmermann) y Androthrips ramachandrai Karny (Thysanoptera, Phlaeothripidae), primeras citas para la Argentina. Revista de la Facultad de Ciencias Agrarias 43(1):253-260. 
Boyd JR., D. W. \& Held, D. W. 2006. Androthrips ramachandrai (Thysanoptera: Phlaeothripidae): an introduced thrips in the United States. Florida Entomologist 89:455-458.

Cambero-Campos, J.; Valenzuela-García, R.; Carvajal-Cazola, C.; Ríos-Velasco, C. \& García-Martínez, O. 2010. New records for Mexico: Gynaikothrips uzeli, Androthrips ramanchandrai (Thysanoptera: Phlaeothripidae) and Montandoniola confusa (Hemiptera: Anthocoridae). Florida Entomologist 93(3):470-472.

Cavalleri, A.; Lima, M. G. A.; Melo, F. S. \& Mendonça Jr., M. S. 2011 New records of Thrips (Thysanoptera) species in Brazil. Neotropical Entomology 40(5):628-630.

Crespi, B. J. 1993. Sex allocation ratio selection in Thysanoptera. In: Wrensch, D. L. \& EBbert, M. A. eds. Evolution and diversity of sex ratio in insects and mites. New York, London, Chapman \& Hall, p. 214-233

De Melo, F. S.; Cavalleri, A. \& Mendonça Jr., M. S. 2013. Predation of Gynaikothrips uzeli (Thysanoptera: Phlaeothripidae) by Androthrips ramachandrai (Thysanoptera: Phlaeothripidae). Florida Entomologist 96(3):859-863.

DobBs, T. T. \& Boyd JR., D. W. 2006. Status and distribution of Montandoniola moraguesi (Puton) (Hemiptera: Anthocoridae) in the United States. Florida Entomologist 89:41-46.

Farong, S.; Yousheng, Z; HunnPInG, Z. \& QIONG, S. 1995. The biological characteristics of Gynaikothrips uzeli Zimmerman. Journal Northwest Forestry College 10(2):104-108.

FUNASAKI, G. Y. 1966. Studies on the life cycle and propagation technique of Montandoniola moraguesi (Puton) (Heteroptera: Anthocoridae). Proceedings of the Hawaiian Entomological Society 19(2):209-211.

Garita-Cambronero, J. \& Lizano-Fallas, V. 2006. Determinación de dimorfismo sexual de Gynaikothrips garitacambroneroi (Thysanoptera: Phlaeotripidae) inductor de agallas em Ficus benjamina. Métodos en Ecología y Sistemática (MES) 1(1):10-14.

Gonçalves-Alvim, S. J. \& Fernandes, G. W. 2001. Comunidades de insetos galhadores (Insecta) em diferentes fitofisionomias do cerrado em Minas Gerais. Revista Brasileira de Zoologia 18:289-305.

Held, D. W.; Boyd, H.; Lockley, T. \& Edwards, G. B. 2005. Gynaikothrips uzeli (Thysanoptera: Phlaeothripidae) in the southeastern United States: distribution and review of biology. Florida Entomologist 88(4):538540 .

Kaufmann, S.; McKey, D. B.; Hossaert-McKey, M. \& Horvitz, C. C. 1991. Adaptations for a two-phase seed dispersal system involving vertebrates and ants in a hemiepiphytic fig (Ficus microcarpa: Moraceae). American Journal of Botany 78(7):971-977.

Kumm, S. \& Moritz, G. 2008. First detection of Wolbachia in arrhenotokous populations of thrips species (Thysanoptera: Thripidae and Phlaeothripidae) and its role in reproduction. Environmental Entomology 37:1422-1428.
Mascarenhas, A. L. S.; Waldschmidt, A. M. \& Silva JR., J. C. 2015. Population structure and genetic diversity in Gynaikothrips uzeli (Thysanoptera: Phlaeothripidae): is there a correlation between genetic and geographic proximity? Genetics and Molecular Research 14(3):9793-9803.

Monteiro, R. C. \& Mound, L. A. 2012. Thysanoptera. In: Rafael, J. A.; Melo, G. A. R.; Carvalho, C. J. B.; Casari, S. A. \& Constantino, R. eds. Insetos do Brasil: Diversidade e Taxonomia. Ribeirão Preto, Holos, p. 407-422

Mound, L. A. 2005. Thysanoptera: Diversity and interactions. Annual Review of Entomology 50:247-269.

Mound, L. A.; Wang, C. \& OKaJima, S. 1995. Observations in Taiwan on the identity of the Cuban laurel thrips (Thysanoptera: Phlaepothripidae). Journal of the New York Entomological Society 103:185-190.

Nadel, H.; Frank, J. H. \& Knight JR., R. J. 1991. Escapees and accomplices: The naturalization of exotic Ficus and their associated faunas in Florida. Insect Behavioral Ecology 75:29-38.

PAIne, T. D. 1992. Cuban Laurel Thrips (Thysanoptera: Phlaeothripidae) biology in Southern California: seasonal abundance, temperature dependent development, leaf suitability and predation. Annals of the Entomological Society of America 85(2):164-172.

Pluot-Sigwalt, D.; Streito, J. C. \& MatocQ, A. 2009. Is Montandoniola moraguesi (Puton, 1896) a mixture of different species? (Hemiptera: Heteroptera: Antocoridae). Zootaxa 2208:25-43.

Quicke, D. L. J. 1997. Parasitic wasps. London, Chapman and Hall. 470p.

Reschke, A.; Marques, L. M. \& Mayworm, M. A. S. 2007. Atividade antibacteriana de Ficus benjamina L. (Moraceae). Revista Brasileira de Plantas Medicinais 9(2):67-70.

Retana-Salazar, A. P. \& Sánchez-Chacón, E. 2009. Anatomía de la agalla em Ficus benjamina (Moraceae) associada a "thrips" (Tubulifera: Phlaeothripidae). Revista de Biología Tropical 57(1):179-186.

RotenBerG, D. \& Whitfield, A. E. 2010. Analysis of expressed sequence tags for Frankliniella occidentalis, the western flower thrips. Insect Molecular Biology 19(4):537-551.

Santos, E. \& Ramalho, R. S. 1997. O gênero Ficus (Moraceae) L. em Viçosa-MG. Ceres 44:646-665.

SAS Institut. 2003. SAS/STAT. User's guide. Versão 8.0. Cary, SAS Institute Inc.

Sepúlveda Cano, P.; Ocampo Corrales, L. F.; Gaviria Rivera, A. M. \& Rubio Gómez, J. D. 2009. Trips (Thysanoptera) asociados a agallas de Ficus benjamina (Linnaeus, 1767) (Moraceae) en la región central de Colombia. Revista Facultad Nacional de Agronomía 62(2):5081-5087.

TERRY, I. 1997. Host selection, communication and reproductive behavior In: Lewis, T. ed. Thrips as Crop Pests. New York, CAB International Oxon, p. 459-489.

Tree, D. J. \& WAlter, G. H. 2009. Diversity of host plant relationships and leaf galling behaviours within a small genus of thrips - Gynaikothrips and Ficus in south east Queensland, Australia. Australian Journal of Entomology 48:269-275. 